\title{
Social network, environmental cognition and organic fertilizer application behavior of small farmers
}

\author{
PENG $\mathrm{Li}^{1}$ and YANG Qingxian ${ }^{1 *}$ \\ 1211 Huimin Road, Wenjiang District, Chengdu City, Sichuan Province, China
}

\begin{abstract}
Small farmers are the main organizational form of agricultural production and management in China, and it is very important to study their organic fertilizer application behavior to promote the development of green agriculture in China. Based on the survey data of 334 small farmers in Sichuan Province, this paper uses bivariate Probit model to analyze the influence of social network and environmental cognition on organic fertilizer application behavior. The research shows that:(1) The application of commercial organic fertilizer and farmyard manure by small farmers has a significant complementary effect.(2) Social network has a significant positive impact on organic fertilizer application behavior, and there are significant differences between kinship social network and friendship social network on organic fertilizer application behavior.(3) The level of environmental cognition has a significant positive effect on the application behavior of organic fertilizer. Therefore, it is necessary not only to make full use of and expand the social network of small farmers, but also to pay attention to improving their environmental awareness and promoting organic fertilizer application behavior.
\end{abstract}

\section{Introduction}

As one of the important agricultural production factors, chemical fertilizer has played a positive role in improving grain yield and ensuring national food security. However, the extensive agricultural development mode for a long time has made China one of the countries with the largest amount of chemical fertilizer in the world ${ }^{[1]}$. According to statistics, the intensity of chemical fertilizer application in 2019 is as high as $325.65 \mathrm{~kg} / \mathrm{hm} 2$, which is much higher than the internationally recognized safety limit of $225 \mathrm{~kg} / \mathrm{hm} 2$. Excessive input of chemical fertilizer has caused negative problems such as agricultural non-point source pollution and soil fertility decline, which has affected and restricted the green and sustainable development of China's agriculture ${ }^{[2]}$.Under this grim situation, the No.1 Document of the Central Committee in 2021 proposed to continuously promote the reduction and efficiency increase of chemical fertilizers and pesticides and promote the development of green agriculture. Thus, how to promote farmers' input of organic fertilizer has become an important practical problem.

The existing literature mainly develops organic fertilizer application behavior from three aspects. First, personal characteristics and cognition, farmers' age and education level have significant negative effects on farmers' organic fertilizer application behavior ${ }^{[3]}$; The higher farmers' awareness of the effect of organic fertilizer application, the higher their probability of applying organic fertilizer ${ }^{[4]}$; Second, in terms of family and production characteristics, farmers' family income ${ }^{[5]}$, agricultural labor force ${ }^{[6]}$, non-agricultural employment ${ }^{[7]}$, land scale ${ }^{[8]}$ and soil fertility ${ }^{[9]}$ significantly affect farmers' organic fertilizer application behavior.The larger the land scale, the more favorable it is for farmers to apply organic fertilizer. However,with the fragmentation of land and the improvement of soil fertility, farmers' willingness to apply organic fertilizer decreases instead ${ }^{[9]}$. In addition, external factors such as whether to participate in agricultural insurance ${ }^{[10]}$, stability of land property rights [11] and policy incentives ${ }^{[12]}$ also affect farmers' fertilization behavior. Most previous studies analyzed farmers' organic fertilizer application behavior based on the assumption of rational economic man, but farmers' decision-making behavior is often not isolated. Under the condition of limited cognition, social relations play an important role in shaping behavior ${ }^{[13]}$. China's rural areas are a typical relational society, and farmers' economic behavior is embedded in the social network formed by interaction with others. Yang Haiyu et al. ${ }^{[14]}$ found that the clan-based social network of farmers promoted the choice of direct sales channels of the company. Jiang Weijun et al. ${ }^{[15]}$ pointed out that social networks further affect the willingness to adopt technology through trust and learning mechanisms.Under the condition of mastering the relevant information of organic fertilizer technology,farmers' own cognition is also very important. As a green production behavior, farmers' environmental cognition will also affect farmers' decision-making. Previous studies have shown that farmers not only maintain economic rationality but also ecological rationality in production ${ }^{[16]}$. The research by Huang Yanzhong and Luo Xiaofeng ${ }^{[2]}$ shows that farmers' ecological cognition is the main power source for

*Corresponding author: 1140634457@qq.com 
adopting organic fertilizer substitution technology, and the influence degree is greater than the influence of economic benefit cognition on organic fertilizer application.

The existing literature has done a lot of research on the application behavior of organic fertilizer, but there is still room for further improvement.First,in terms of research objects, most studies treat farmers as a whole, and seldom start from the perspective of small farmers. Although the current farmers are gradually divided into different types such as traditional small farmers, large grain growers and farmers, small farmers are still the main body of agricultural production and management in the future,so it is necessary to pay attention to the fertilization behavior of small farmers. Second, from the research perspective, the existing literature pays attention to the influence of social network or farmers' cognition on organic fertilizer application behavior, but few literatures bring social network and environmental cognition into the same analysis framework to analyze their influence on technology adoption. Third, in terms of research content, most studies do not subdivide organic fertilizer and refer to organic fertilizer as a general term, ignoring the correlation between different organic fertilizer application technologies. Based on the survey data of 334 small farmers in Sichuan Province, this paper uses bivariate Probit model to analyze whether there is complementary or substitution effect between different technical choices when farmers are faced with commercial organic fertilizer and farmyard manure application choices.Is there any difference in the influence of social network and environmental cognition on different technology choices? So as to provide reference for the development of green agriculture in China.

\section{Theoretical analysis and research hypothesis}

\subsection{Social network and organic fertilizer application behavior}

Social network mainly refers to the relationship network formed by mutual communication between groups ${ }^{[17]}$. At present, China's economic construction and market are not perfect, and social network still has a far-reaching impact on rural areas with backward formal system. The mechanism of social network on farmers' organic fertilizer application behavior is at least reflected in the following aspects:First, information acquisition. Farmers are typical information vulnerable groups and lack information channels ${ }^{[18]}$.Social networks play an important role in transmitting information and reducing search costs. The larger the relationship network, the more likely farmers are to know more information, and the more they can correctly contact and understand this technology, thus increasing the probability of organic fertilizer application. Second, exchange and study. Social network, as the main environment for farmers to learn from each other, is conducive to reducing the uncertainty of technology adoption and promoting the knowledge diffusion of new agricultural technologies through mutual communication and learning ${ }^{[15]}$. Third, cooperation and mutual benefit.
Agricultural technology conversion usually means higher cost input, while social network can provide farmers with financial, labor and technical support, reduce the cost pressure of technology conversion, and thus promote the application of organic fertilizer ${ }^{[19]}$.

In the current Chinese rural society, farmers are mainly individuals or families, and form a social network structure of differential order pattern according to the close relationship of blood and geography. One is a social network based on "kinship" and focusing on strength, and the other is a social network based on "karma" or "geography" and focusing on universality ${ }^{[20]}$. The kinship social network plays a stronger role in information transmission, learning and communication by virtue of its emotional advantages, while the friendship social network can provide more extensive and non-repetitive information, changing the existing cognition and behavior habits of farmers. Based on this, the following assumptions are put forward:

Hypothesis 1: Social network has a positive impact on organic fertilizer application behavior, and the effects of kinship social network and friendship social network on organic fertilizer application behavior are different.

\subsection{Environmental cognition and organic fertilizer application behavior}

According to the theory of planned behavior, the subject's cognition will affect his willingness to participate and then affect his behavior. Environmental cognition belongs to human psychological factors. Behavioral economics believes that human beings will be affected by psychological factors in the decision-making process ${ }^{[21]}$. The higher the level of farmers' environmental awareness, the more they understand the relevant environmental knowledge and environmental protection policies, and the more they can recognize the seriousness of the current rural environmental pollution, that is, the more likely they are to apply organic fertilizer to alleviate the problem of agricultural non-point sources ${ }^{[22]}$. On the one hand, farmers, as decision makers of organic fertilizer application, may tend to choose organic fertilizer when fertilizing if they realize that organic fertilizer can improve soil fertility, improve soil structure and protect agricultural ecological environment. On the other hand,farmers, as the direct bearers of the deterioration of rural ecological environment, are more willing to change their behavior to maintain or even improve the existing environmental conditions in order to get a better environmental perception experience, thus holding a positive attitude towards the application of organic fertilizer.Based on this, the following assumptions are proposed:

Hypothesis 2: Environmental cognition has a positive impact on organic fertilizer application behavior. 


\section{Data sources, variable selection and descriptive statistics}

\subsection{Data source}

The data comes from the field investigation of farmers in Sichuan Province in July 2019, and adopts the method of stratified sampling and equal probability random sampling. According to the research of $\mathrm{Xu}$ et al. ${ }^{[23]}$, all districts and counties in Sichuan Province are clustered into five categories according to the per capita industrial output value from high to low, and one county sample is randomly selected from each category to obtain Jiangyou city, Zhaohua country, Guang'an city, Shehong county, Ziliujing and Yantan District. Then, the villages and towns in the sample districts and counties are divided into high and low income groups according to the ranking of per capita industrial output value. Each group randomly selects one township, each township randomly selects two villages, and each village randomly selects 20 households. A total of 400 questionnaires were obtained. According to the definition of World Bank et al. ${ }^{[24]}$, small farmers are farmers whose cultivated land scale is less than 2 hectares (30 mu). After sorting out and deleting invalid questionnaires, 334 valid questionnaires for small farmers were finally obtained.

\subsection{Variable selection}

(1) Dependent variables. Organic fertilizer application behavior of small farmers was selected as dependent variable. Organic fertilizer includes commercial organic fertilizer and farmyard manure, which mainly refers to fertilizer made from crop straw, livestock manure and other raw materials through accumulation and fermentation.(2) Core variables. Drawing on the research of Fang Ran ${ }^{[25]}$ and Yang Zhihai ${ }^{[26]}$, two variables, kinship social network and friendship social network, are set up in this paper. The strength and scale of social network are characterized by the number of relatives visiting in 2018 Spring Festival and the number of fellow villagers and friends visiting in 2018 Spring Festival. Referring to the

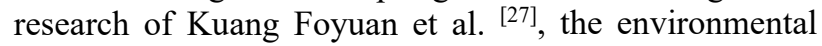
cognition level of farmers is investigated by scoring the assigned values of 10 questions in Table 2. If the answer is correct, 1 point is counted, and if the answer is wrong or does not know, 0 point is counted. (3) Control variables. Considering the influence of farmers' individual endowment differences, gender, age and education level are selected to reflect farmers' individual characteristics; Select whether there are village cadres or party members in the family, and the proportion of family agricultural labor force and non-agricultural income reflects the characteristics of the family; Select cultivated land scale, cultivated land quality and family farming to reflect production characteristics; The regional characteristic variables are expressed by the virtual variables of the county where the farmers are located.
Table1. Farmers' environmental cognition level

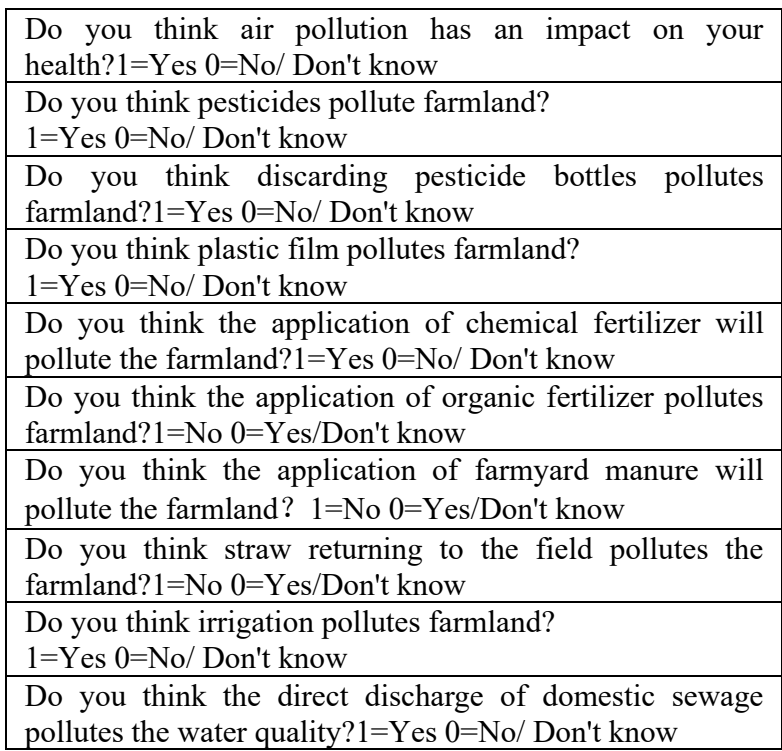

\subsection{Variable descriptive statistics}

The variable definitions and data descriptions involved in this paper are shown in Table 2.In terms of social network, relatives mainly visit during the Spring Festival, while friends visit less, with an average of 4.874 and 2.835 respectively. In terms of environmental awareness, farmers' environmental awareness level is not high, with an average of 5.722. For control variables, there are more men than women, accounting for $58.7 \%$. The respondents are generally older, with an average age of 56.293 years. The education level is generally not high, and the average number of years of education per capita is 5.138 years. The average number of agricultural laborers in families is 1.787 , and $22.2 \%$ of farmers have party members or village cadres in their families. Most of the household income comes from non-agricultural income, with an average value of $88.9 \%$, which is in line with the characteristics of non-agricultural in rural areas today. The average area of cultivated land per household is $4.824 \mathrm{mu}$, and the quality of cultivated land is mostly close to the medium level, with an average value of 1.950 .

Table2. Meaning and descriptive statistics of variables related to farmers' organic fertilizer application behavior

\begin{tabular}{|c|c|c|c|}
\hline Variable & $\begin{array}{c}\text { Definition and } \\
\text { assignment }\end{array}$ & Mean & Standard \\
\hline $\begin{array}{c}\text { Dependent } \\
\text { variable }\end{array}$ & $1=$ Yes $0=\mathrm{No}$ & 0.156 & 0.363 \\
\hline $\begin{array}{c}\text { Whether to } \\
\text { apply } \\
\text { commercial } \\
\text { organic } \\
\text { fertilizer }\end{array}$ & $1=$ Yes $0=\mathrm{No}$ & 0.632 & 0.483 \\
\hline $\begin{array}{c}\text { Whether to } \\
\text { apply farmyard } \\
\text { manure }\end{array}$ & & & \\
\hline Core Variables & & \\
\hline
\end{tabular}




\begin{tabular}{|c|c|c|c|}
\hline $\begin{array}{l}\text { Kinship social } \\
\text { network }\end{array}$ & $\begin{array}{l}\text { Number of } \\
\text { relatives visiting } \\
\text { your home during } \\
\text { the Spring Festival } \\
\text { (households) }\end{array}$ & 4.874 & 3.590 \\
\hline $\begin{array}{l}\text { Friendship } \\
\text { social network }\end{array}$ & $\begin{array}{c}\text { Number of } \\
\text { friends/villagers } \\
\text { visiting your home } \\
\text { during the Spring } \\
\text { Festival } \\
\text { (households) }\end{array}$ & 2.835 & 2.981 \\
\hline $\begin{array}{l}\text { Environmental } \\
\text { cognition }\end{array}$ & $\begin{array}{c}\text { Knowledge score } \\
\text { of environmental } \\
\text { problems }\end{array}$ & 5.722 & 2.534 \\
\hline Gender & $\begin{array}{l}\text { Sex of head of } \\
\text { household? } 1= \\
\text { Male } 0=\text { Female }\end{array}$ & 0.587 & 0.493 \\
\hline Age & $\begin{array}{c}\text { Age of head of } \\
\text { household (years) }\end{array}$ & 56.293 & 11.531 \\
\hline $\begin{array}{l}\text { Years of } \\
\text { education }\end{array}$ & $\begin{array}{c}\text { Years of education } \\
\text { of the head of } \\
\text { household (years) }\end{array}$ & 5.138 & 3.970 \\
\hline $\begin{array}{l}\text { Are there } \\
\text { village cadres or } \\
\text { party members } \\
\text { at home }\end{array}$ & $\begin{array}{l}\text { Are there village } \\
\text { cadres or party } \\
\text { members in the } \\
\text { family? } \\
1=\text { Yes } 0=\text { No }\end{array}$ & 0.222 & 0.416 \\
\hline $\begin{array}{l}\text { Number of } \\
\text { agricultural } \\
\text { labor force }\end{array}$ & $\begin{array}{l}\text { Number of family } \\
\text { agricultural labor } \\
\text { force (person) }\end{array}$ & 1.787 & 0.820 \\
\hline $\begin{array}{l}\text { Proportion of } \\
\text { non-agricultural } \\
\text { income }\end{array}$ & $\begin{array}{l}\text { Proportion of non- } \\
\text { agricultural } \\
\text { income to total } \\
\text { income }(\%)\end{array}$ & 0.889 & 0.202 \\
\hline $\begin{array}{l}\text { Cultivated land } \\
\text { scale }\end{array}$ & $\begin{array}{l}\text { Area of cultivated } \\
\text { land under } \\
\text { operation }(\mathrm{mu})\end{array}$ & 4.824 & 3.330 \\
\hline $\begin{array}{l}\text { Cultivated land } \\
\text { quality }\end{array}$ & $\begin{array}{l}\text { The quality of } \\
\text { cultivated land? } \\
1=\text { worse than } \\
\text { average } 2=\text { same } \\
\text { as average } 3= \\
\text { better than average }\end{array}$ & 1.950 & 0.620 \\
\hline $\begin{array}{l}\text { Whether or not } \\
\text { to breed }\end{array}$ & $\begin{array}{c}\text { Whether or not to } \\
\text { breed } ? 1=\text { Yes } \\
0=\text { No }\end{array}$ & 0.695 & 0.461 \\
\hline Guangan & $\begin{array}{c}1=\text { Guangan } \\
0=\text { Other } \\
\text { provinces }\end{array}$ & 0.216 & 0.412 \\
\hline Shehong & $\begin{array}{c}1=\text { Zhaohua } \\
0=\text { Other } \\
\text { provinces }\end{array}$ & 0.189 & 0.392 \\
\hline Jiangyou & $\begin{array}{c}1=\text { Jiangyou } \\
0=\text { Other } \\
\text { provinces }\end{array}$ & 0.183 & 0.387 \\
\hline Zigong & $\begin{array}{l}1=\text { Zigong } \\
0=\text { Other } \\
\text { provinces }\end{array}$ & 0.201 & 0.401 \\
\hline
\end{tabular}

\section{Model construction and empirical test}

\subsection{Model building}

Whether small farmers apply commercial organic fertilizer and whether they apply farmyard manure are binomial choice variables, and some unobservable factors will affect the choice of these two behaviors at the same time. Therefore, the two decisions are not independent of each other. If $y_{1}$ and $y_{2}$ are used to represent the decision of small farmers on the application of commercial organic fertilizer and farmyard manure, and $y_{1}=1$ means the application of commercial organic fertilizer, while $y_{1}=0$ means no application of commercial organic fertilizer. $y_{2}=1$ means application of farmyard manure, while $\mathrm{y}_{2}=0$ means no application of farmyard manure. That is, there are four results: $(0,0),(1,0),(0,1),(1,1)$. Because the bivariate Probit model allows the correlation between the error terms of different equations, a bivariate Probit model is established to analyze the influencing factors of social network and environmental cognition on the organic fertilizer application behavior of small farmers. The specific form of model setting is:

$$
\begin{aligned}
& y_{1}^{*}=\beta_{1}^{\prime} x_{1}+\varepsilon_{1} \\
& y_{2}^{*}=\beta_{2}^{\prime} x_{2}+\varepsilon_{2} \\
& y_{j}=\left\{\begin{array}{cl}
1, \text { if } y_{j}^{*}>0 \\
0, & \text { other }
\end{array}\right.
\end{aligned}
$$

Among them, $\varepsilon_{1}$ and $\varepsilon_{2}$ meet the following assumptions:

$$
\left\{\begin{array}{c}
E\left(\varepsilon_{1}\right)=E\left(\varepsilon_{2}\right)=0 \\
\operatorname{var}\left(\varepsilon_{1}\right)=\operatorname{var}\left(\varepsilon_{2}\right)=1 \\
\operatorname{cov}\left(\varepsilon_{1}, \varepsilon_{2}\right)=\rho
\end{array}\right.
$$

In (1) (2), $\mathrm{y}_{1} *$ and $\mathrm{y}_{2} *$ are unobservable latent variables, and $y_{1}$ and $y_{2}$ are the final result variables as explained variables. $x_{1}$ and $x_{2}$ are independent variables affecting farmers' application of commercial organic fertilizer and farmyard manure, respectively, $\beta_{1}^{\prime}, \beta_{2}^{\prime}$ are corresponding estimation coefficients. $\varepsilon_{1}$ and $\varepsilon 2$ are error terms and obey two-dimensional normal distribution. $\rho$ is the correlation coefficient of $\varepsilon_{1}$ and $\varepsilon_{2}$, when $=0$,it means that $\varepsilon_{1}$ and $\varepsilon_{2}$ are not correlated; If $>0, y_{1}$ and $y_{2}$ are complementary effects, and if $<0, y_{1}$ and $y_{2}$ are substitution effects.

\subsection{Empirical results and analysis}

In this study, Stata16.0 software was used to test the influence of social network and environmental cognition on farmers' organic fertilizer application behavior. The results are shown in Table 3. On the whole, the model fits well, the core variables basically pass the significance test, and the coefficient symbol is basically consistent with the expected direction. Wald test shows that the coefficient is positive and significant at the level of $5 \%$, rejecting the original hypothesis of $\rho=0$, so it is necessary to use 
bivariate Probit model, and the application of commercial organic fertilizer and farmyard manure by farmers is interactive and has strong complementarity.

The results show that kinship social network has a positive effect on the application of commercial organic fertilizer and farmyard manure by small farmers, which is significant at the level of $10 \%$ and $5 \%$, respectively, while friendship social network has no significant effect on the application of commercial organic fertilizer by small farmers, but has a positive effect on the application of farmyard manure, which is significant at the level of $10 \%$. Hypothesis 1 is confirmed. This means that under the social background of rural acquaintances, farmers will not only make fertilization decisions according to their own agricultural production experience, but also decide their own fertilization methods with reference to other farmers around them. Furthermore, the members in the kinship social network are more closely related, the degree of mutual trust is stronger, and it is easier to realize learning imitation and risk sharing within the group, which makes farmers show "herd effect" in agricultural production. Although friendship social network can provide heterogeneous information and resources for farmers and enrich their knowledge, it is also more difficult to obtain substantial help, thus having no significant impact on the application of organic fertilizer. Environmental cognition has a significant and positive impact on the application of commercial organic fertilizer and farmyard manure by small farmers at the level of $5 \%$ and $10 \%$, respectively. This means that farmers with higher environmental awareness are more aware of the harmfulness of current agricultural non-point source pollution and the importance of adopting organic fertilizer technology, so they are more willing to apply organic fertilizer. Hypothesis 2 is confirmed.

Among the control variables, education level has a significant positive impact on organic fertilizer application. It shows that the higher the education level, the better farmers can understand the advantages of applying organic fertilizer and improve the behavior of applying organic fertilizer; Families with village cadres or party members are more willing to apply commercial organic fertilizer than ordinary farmers. Generally speaking, families with political identity actively respond to the call of the state and are more willing to invest commercial organic fertilizer in production; The proportion of non-agricultural income has a negative impact on the application of farmyard manure; The process of farmyard manure accumulation is time-consuming and laborious; The shortage of labor caused by non-agriculturalization will not be conducive to the application of farmyard manure; The quality of cultivated land has a positive impact on the application of commercial organic fertilizer by small farmers. In order to maintain high sustainable production capacity, small farmers are more willing to apply commercial organic fertilizer to good quality land; Whether farming has a positive impact on the application of farmyard manure by small farmers, and farming can provide low-cost farmyard manure raw materials for small farmers and promote the application of farmyard manure.
Table3. Estimation results of bivariate probit model

\begin{tabular}{|c|c|c|c|c|}
\hline \multirow[t]{2}{*}{ Variable } & \multicolumn{2}{|c|}{$\begin{array}{c}\text { Commercial } \\
\text { organic fertilizer }\end{array}$} & \multicolumn{2}{|c|}{$\begin{array}{c}\text { Farmyard } \\
\text { manure }\end{array}$} \\
\hline & $\begin{array}{l}\text { Coeffic } \\
\text { ient }\end{array}$ & Z-test & $\begin{array}{l}\text { Coeffi } \\
\text { cient }\end{array}$ & Z-test \\
\hline \multicolumn{5}{|l|}{ Core variables } \\
\hline $\begin{array}{c}\text { Kinship social } \\
\text { network }\end{array}$ & $0.043^{*}$ & 1.772 & $\begin{array}{c}0.063^{*} \\
*\end{array}$ & 2.484 \\
\hline $\begin{array}{c}\text { Friendship social } \\
\text { network }\end{array}$ & 0.018 & 0.611 & $0.052^{*}$ & 1.879 \\
\hline $\begin{array}{l}\text { Environmental } \\
\text { cognition }\end{array}$ & $0.081^{* *}$ & 2.344 & $0.055^{*}$ & 1.810 \\
\hline \multicolumn{5}{|l|}{ Control variables } \\
\hline Gender & -0.090 & -0.444 & 0.012 & 0.074 \\
\hline Age & -0.004 & -0.433 & 0.011 & 1.557 \\
\hline $\begin{array}{c}\text { Years of } \\
\text { education }\end{array}$ & $0.067^{* *}$ & 2.562 & $\begin{array}{c}0.047^{*} \\
*\end{array}$ & 2.221 \\
\hline $\begin{array}{l}\text { Are there village } \\
\text { cadres or party } \\
\text { members at home }\end{array}$ & $0.511^{* *}$ & 2.442 & 0.199 & 1.051 \\
\hline $\begin{array}{c}\text { Number of } \\
\text { agricultural labor } \\
\text { force }\end{array}$ & -0.024 & -0.226 & 0.153 & 1.588 \\
\hline $\begin{array}{c}\text { Proportion of } \\
\text { non-agricultural } \\
\text { income }\end{array}$ & -0.605 & -1.239 & $\bar{*}_{* *}^{-}$ & -2.870 \\
\hline $\begin{array}{l}\text { Cultivated land } \\
\text { scale }\end{array}$ & -0.012 & -0.392 & 0.014 & 0.525 \\
\hline $\begin{array}{l}\text { Cultivated land } \\
\text { quality }\end{array}$ & $0.284^{* *}$ & 2.004 & 0.155 & 1.262 \\
\hline $\begin{array}{c}\text { Whether or not to } \\
\text { breed }\end{array}$ & 0.236 & 1.119 & $0.462^{*}$ & 2.784 \\
\hline Shehong & 0.113 & 0.382 & 0.025 & 0.105 \\
\hline Jiangyou & 0.116 & 0.386 & 0.055 & 0.229 \\
\hline Zigong & 0.359 & 1.169 & -0.240 & -0.930 \\
\hline Guangan & 0.448 & 1.537 & 0.188 & 0.773 \\
\hline _cons & $\begin{array}{c}- \\
2.512^{* *} \\
*\end{array}$ & -3.015 & ${ }^{-}-254^{*}$ & -1.758 \\
\hline rho & \multicolumn{4}{|c|}{$0.264^{* *}$} \\
\hline $\begin{array}{c}\text { Log } \\
\text { pseudolikelihood }\end{array}$ & \multicolumn{4}{|c|}{-309.9667} \\
\hline Prob $>$ Chi 2 & \multicolumn{4}{|c|}{0.0000} \\
\hline $\mathrm{N}$ & \multicolumn{4}{|c|}{334} \\
\hline
\end{tabular}

Note: $* * *, 、 * * *$ respectively indicate significant levels of $10 \%, 5 \%$, and $1 \%$. The following table is the same.

\subsection{Robustness test}

Considering that social environment plays an important role in shaping individual cognition, social network, as a special form of social environment, may also have an impact on farmers' environmental cognition. The more communication between farmers and people with strong environmental awareness, the deeper understanding of the harm of excessive application of chemical fertilizer and the benefits of applying organic fertilizer, thus affecting farmers' fertilization behavior. In order to avoid the influence of multicollinearity between social network and environmental cognition, social network and environmental cognition are added to the model for regression. The results show that social network and 
environmental cognition have no change in the direction and significance of organic fertilizer application, so the research results of this paper are relatively stable.

Table4. Robustness test

\begin{tabular}{|c|c|c|c|c|}
\hline & \multicolumn{2}{|c|}{$\begin{array}{c}\text { Bivariate Probit } \\
\text { model I }\end{array}$} & \multicolumn{2}{c|}{ Bivariate Probit model II } \\
\hline Variable & $\begin{array}{c}\text { Commerci } \\
\text { al organic } \\
\text { fertilizer }\end{array}$ & $\begin{array}{c}\text { Farmyard } \\
\text { manure }\end{array}$ & $\begin{array}{c}\text { Commerci } \\
\text { al organic } \\
\text { fertilizer }\end{array}$ & $\begin{array}{c}\text { Farmyard } \\
\text { manure }\end{array}$ \\
\hline $\begin{array}{c}\text { Core } \\
\text { Variables }\end{array}$ & & & & \\
\hline $\begin{array}{c}\text { Kinship } \\
\text { social } \\
\text { network }\end{array}$ & $0.050^{* *}$ & $0.070^{* * *}$ \\
$(2.053)$ & $(2.705)$ & & \\
\hline $\begin{array}{c}\text { Friendshi- } \\
\text { p social } \\
\text { network }\end{array}$ & 0.013 & $0.047^{*}$ & & \\
\hline $\begin{array}{c}\text { Environm } \\
\text { ental } \\
\text { cognition }\end{array}$ & $0.421)$ & $(1.734)$ & $0.085^{* *}$ & $0.063^{* *}$ \\
\hline $\begin{array}{c}\text { Control } \\
\text { variables }\end{array}$ & Controlled & Controlled & Controlled & Controlled \\
\hline Rho & \multicolumn{2}{|c|}{0.283} & \multicolumn{2}{c|}{0.301} \\
\hline $\begin{array}{c}\text { Log Like- } \\
\text { lihod }\end{array}$ & -313.6931 & \multicolumn{2}{c|}{-317.4392} \\
\hline $\begin{array}{c}\text { Prob }>\text { Chi2 } \\
\text { nample }\end{array}$ & \multicolumn{2}{|c|}{0.0000} & \multicolumn{2}{c|}{0.0000} \\
\hline $\begin{array}{c}\text { Sample } \\
\text { size }\end{array}$ & \multicolumn{2}{|c|}{334} & \multicolumn{2}{c|}{334} \\
\hline
\end{tabular}

\section{Summary and suggestions}

\subsection{Summary}

(1)The behavior of small farmers applying commercial organic fertilizer and farmyard manure has complementary effects.(2)Social network has a positive effect on organic fertilizer application behavior, and the influence of kinship social network and friend social network on organic fertilizer application behavior is different. Genetic social network has a positive impact on farmers' application of commercial organic fertilizer and farmyard manure, while friendly social network has a significant positive impact on farmers' application of farmyard manure, but has no significant impact on the application of commercial organic fertilizer.(3)The environmental cognition of small farmers can significantly promote the application behavior of organic fertilizer. That is, farmers' environmental cognition is also one of the most intuitive factors affecting farmers' organic fertilizer application behavior.

\subsection{Suggestions}

According to the above conclusions, the following enlightenment is obtained:

(1) Pay attention to the cultivation and promotion of social networks. Farmers are encouraged to use the relationship resources of relatives and friends to strengthen their network ties, and to create a community cultural atmosphere of mutual benefit and mutual assistance by organizing rural cultural activities and production mutual assistance activities. Combined with the characteristics of social networks, through the establishment of "village-level demonstration households" and "demonstration sites" and other forms, the strong trust characteristics of kinship social networks are brought into play to create convenient conditions for farmers to realize "learning by watching" and "learning by doing". With the help of modern means such as Internet media, we should build a communication platform between small farmers and agricultural technicians, broaden the circle of friends of farmers, and give full play to the positive role of social networks of friends.

(2)Enhance farmers' environmental awareness level. In the process of formulating policies, the government considers small farmers' environmental awareness as an important policy reference, carries out publicity and education activities on ecological environment-related knowledge, promotes farmers' learning and understanding of legal provisions related to ecological environment protection, and improves their environmental awareness level. At the same time, it also strengthens the publicity of organic fertilizer knowledge, improves farmers' understanding of the application of organic fertilizer, cultivates farmers' positive attitude, and promotes the promotion of organic fertilizer.

(3)Establish a cooperation mechanism for close communication between growers and farmers. On the one hand, it can meet the demand of growers for farmyard manure, on the other hand, it can also solve the pollution problem of livestock manure of farmers, promote the integration of planting and breeding cycle, and promote the development of green agriculture.

\section{References}

1. J.J. Gao, C. Peng and Q.H. Shi. Study on the high amount of chemical fertilizer and the fertilization behavior of small farmers in China-based on the discovery of fixed observation point data in rural areas from 1995 to 2016 [J]. Management World, 2019, 35 (10): 120-132.

2. Y.Z.Huang,X.F. Luo.Fertilizer reduction substitution: farmers' strategy choice and influencing factors [J].Journal of South China Agricultural University (Social Science Edition), 2020, 19 (01): 77-87.

3. C.H.Chu,S.Y. Feng,W.W. Zhang. Empirical analysis of farmers' behavior of adopting environmentfriendly agricultural technology-taking organic fertilizer and soil testing and formula fertilization technology as examples [J]. China Rural Economy, 2012 (03): 68-77..

4. L.Q. Zhu, J. Wang, C.J. Wang, et al. Analysis of influencing factors of farmers' willingness to adopt organic fertilizer and chemical fertilizer combined application technology-based on farmers' survey in Jiangsu,Zhejiang and Anhui provinces[J]. Resources and Environment of Yangtze River Basin, 2018, 27 (03): 671-679.

5. T.B.Jiang.Analysis of influencing factors of farmers' fertilization behavior in rural ecological environment construction $[\mathrm{J}]$. Journal of Southwest University for 
Nationalities (Humanities and Social Sciences Edition), 2015, 36 (12): 157-161.

6. Y.Z. Huang, X.F. Luo, D. Liu, et al. Influencing factors of farmers' adoption of organic fertilizer instead of chemical fertilizer technology-an explanation of the phenomenon of high willingness and low behavior [J].Yangtze River Basin Resources and Environment, 2019, 28 (03): 632-641.

7. T.Y. Zhong, X.J. Huang, B.Y. Wang. Effects of nonagricultural employment on farmers' application of organic fertilizer [J]. China Land Sciences, 2011, 25 (11): 67-73.

8. H. Zhou, N. Teruaki, M. Song, et al. Analysis on Factors Influencing Organic Fertilizer Use in China: A Case Study on Wheat Farmers in Six Eastern Provincial-Level Regions [J]. Journal-Faculty of Agriculture Kyushu University, 2014, 59 (1): 215-219.

9. Y.M. Zeng, J.B. Zhang,K. He.Study on rice farmers' willingness to adopt organic fertilizer and its driving factors from the perspective of multi-dimensional family capital [J]. Journal of Ecology and Rural Environment, 2019, 35 (03): 332-338.

10. C. Zhang, C.X. Zhang, H.G Qiu, et al. Influence of Agricultural Insurance Participation Behavior on Farmers' Input-Taking Organic Fertilizer Input as an Example [J]. Agricultural Technology and Economy, 2017 (06): 79-87.

11. H. Lu, P.W. Zhang, H.Hu, et al. "Effect of the graingrowing purpose and farm size on the ability of stable land property rights to encourage farmers to apply organic fertilizers." Journal of Environmental Management 251:109621-109621.

12. X.C. Sang, X.F. Luo, Y.Z. Huang, et al. Policy incentives, ecological cognition and farmers' organic fertilizer application behavior-based on a moderated mediating effect model $[\mathrm{J} / \mathrm{OL}]$. Chinese Journal of Ecological Agriculture (Chinese and English):111[2021-05-24]. https://doi.org/10.13930/j.cnki.cjea.200978.

13. M. Granovetter. Economic Action and Social Structure:The Problem of Embeddedness [J]. American Journal of Sociology, 1985, 91(3):481-510.

14. H.Y.Yang,X.G.Li, C.Y. Zhang,et al. Informatization, social network and farmers' choice of purchasing channels for agricultural materials: a comparison between direct sales and retail stores for agricultural materials[J].Research on Agricultural Modernization, 2020, 41 (03): 474-483.

15. W.J. Jiang, T.W. Yan,X. Jiang, et al. Influence of social network and ecological cognition on farmers' willingness to return straw to field [J].Journal of China Agricultural University, 2019, 24 (08): 203-216.

16. L.Y. Yao, M.J. Zhao, T. Xu. Economic rationality or ecological rationality? Study on Behavioral Logic of Farmers' Cultivated Land Protection [J]. Journal of Nanjing Agricultural University (Social Science Edition), 2016, 16 (05): 86-95 +156.
17. M. Granovetter. Getting a job: a study of contacts and careers [M]. Ind. ed Chicago: The University of Chicago Press, 1995

18. Y.S. Chen, Y.D. Zhu, L. Zhang. Study on Farmers' Choice Behavior of Environmental Protection Agricultural Materials? -Based on experimental economics [J]. Agricultural Economic Issues, 2016, 37 (08): 33-40 +110-111.

19. T.C. Zhang, T.W. Yan, Z. Wang. Social network, income uncertainty and self-employed women's adoption behavior of conservation tillage technology [J]. Agricultural Technology and Economics, 2020 (08): 101-116.

20. L.X.He,Y.Q.Nan,Z.G.Zhang. Aging, Social Network and Family Farming: Evidence from CFPS [J]. Economic Review, 2016 (02): 85-97.

21. W.Z. Yu, X.F. Luo, R.R. Li, et al. Study on the Deviation between Farmers' Green Technology Adoption Willingness and Behavior from the Perspective of Green Cognition [J]. Resource Science, 2017, 39 (08): 1573-1583.

22. H. L. Zhang, J. Y. Li, H. Q. Teng. Cognition of smallholder farmers, external environment and adoption behavior of green agricultural technology-A case study of organic fertilizer [J]. Resources and Environment in Arid Areas, 2020, 34 (06): 8-13.

23. D.D. Xu, S.L. Guo, F.T. Xie, et al. The impact of rural labor migration and household structure on household land use arrangements in mountain areas of Sichuan Province, China.Habitat International, 2017, 70: $72-$ 80.

24. Bank C. Reaching the Rural Poor: A Renewed Strategy for Rural Development [J]. World Bank Publications, 2010, 19 (4): 563573.

25. R. Fang. Research on Quantitative Measurement of China's Localization of Social Capital [M]. Beijing: Social Science Literature Publishing House, 2014.

26. Z.H. Yang. Aging, Social Network and Farmers' Adoption Behavior of Green Production TechnologyVerification of Farmers' Data from Six Provinces in the Yangtze River Basin [J]. China Rural Observation, 2018 (04): 44-58.

27. F.Y. Kuang,M.Q. Chen, $\mathrm{Li}$, et al.Difference analysis of farmers' ecological environment cognition and protection behavior-taking the use of pesticides and fertilizers as an example [J]. Research on Soil and Water Conservation, 2018, 25 (01): 321-326. 